\title{
Bipolar Bozukluk Tanılı Hastalarda Nörokognitif İşlevler ile Nitrik Oksit ve Asimetrik Dimetilarjinin Düzeyleri Arasındaki İlişki
}

\author{
Relationship Between the Levels of Nitric Oxide, Asymmetric Dimethylarginine and \\ Neurocognitive Functions in Patients with Bipolar Disorder
}

\author{
Betül KURTSES GÜRSOY ${ }^{*}$, Nihan TURĞUT ${ }^{2}$, Ayhan VURMAZ ${ }^{3}$ \\ ${ }^{I}$ Düzce Atatürk Devlet Hastanesi Psikiyatri Kliniği, Düzce \\ ${ }^{2}$ Afyon Kocatepe Üniversitesi Tip Fakültesi Psikiyatri AD, Afyon \\ ${ }^{3}$ Afyon Kocatepe Üniversitesi Tip Fakültesi Biyokimya AD, Afyon
}

\begin{abstract}
ÖZ
Amaç: Bu çalışmada bipolar bozukluk tanısı olan hastalarda bilişsel işlevlerin, serum nitrik oksit (NO) ve asimetrik dimetilarjinin (ADMA) düzeyleri ile ilişkisinin belirlenmesi planlanmıştır.

Gereç ve Yöntemler: Çalışmanın örneklemi Afyon Kocatepe Üniversitesi Tıp Fakültesi Psikiyatri Polikliniği tarafindan ayaktan takip edilen, DSM-5'e göre bipolar bozukluk tanısı konulmuş ötimik dönemdeki 45 hasta ile yaş, cinsiyet ve eğitim süresi yönünden eşleştirilmiş 45 sağlıklı gönüllüden oluşturuldu. Çalışmaya katılanlara sosyodemografik veri formu, Hamilton Depresyon Derecelendirme Ölçeği ve Young Mani Derecelendirme Ölçeği uygulandı. Nörokognitif fonksiyonlar Sözel Bellek Süreçleri Testi, Wisconsin Kart Eşleştirme Testi, Stroop Testi ve İz Sürme Testi ile incelendi. Serum NO ve ADMA düzeyleri ELISA kiti kullanılarak ölçüldü.

Bulgular: Yaş, cinsiyet ve eğitim durumu açısından eşleştirilmiş iki grup arasında ailevi psikiyatrik soygeçmiş sorgulamasında anlamlı farklılık ( $\mathrm{p}=0,002)$ olduğu ve hasta grubunun \%31'inin ailesinde bipolar bozukluk olduğu tesbit edildi. Hasta grubunun nöropsikolojik test sonuçlarının kontrol grubundan istatistiksel olarak anlamlı derecede düşük olduğu bulundu. Serum ADMA düzeyinin ise hasta grubunda kontrol grubuna göre daha düşük düzeyde olduğu gözlendi $(\mathrm{p}=0,001)$. ADMA düzeyi ile kendiliğinden hatırlama puanı $(\mathrm{p}=0,037)$, kavramsal düzey tepki yüzdesi $(\mathrm{p}=0,029)$, Stroop Test puanları $(\mathrm{p}=0,043)$ ve İz Sürme A testi süresi $(\mathrm{p}=0,002)$ arasında istatistiki olarak anlamlı ilişki olduğu saptandı.

Sonuç: Bu çalışmanın sonuçlarına göre bipolar bozukluk hastalarında bellek, öğrenme, dikkat, işlem hızı, strateji değiştirme, problem çözme gibi bilişsel alanlarda bozulma olduğu fakat bu bozulmanın serum NO düzeyi ile ilişkisi olmadığı fakat kendiliğinden hatırlama, kavramsal tepki yüzdesi, Stroop Testi tamamlama süresi, İz Sürme A testi süresi puanlarının ADMA ile ilişkisi olduğu belirlenmiştir. Anahtar kelimeler: Bipolar bozukluk; biliş; nitrik oksit; asimetrik dimetilarjinin.
\end{abstract}

\begin{abstract}
Aim: The current study aimed to explore the association between cognitive functions and serum nitric oxide (NO), asymmetric dimethylarginine (ADMA) levels in patients with bipolar disorder.

Material and Methods: The study sample was consisted of patients followed by Afyon Kocatepe University Psychiatry Department outpatient clinic. 45 patients diagnosed with bipolar disorder according to DSM- 5 criteria and 45 volunteers adjusted for gender, age, and education were included. Sociodemographic Data Form, Hamilton Depression Rating Scale and Young Mania Rating Scale were applied to all participants. Neurocognitive functions were assessed with Test of Verbal Memory Processes, Wisconsin Card Sorting Test (WCST), Stroop Test and Trail-Making Test. Serum NO and ADMA levels were measured using ELISA kit.

Results: It was determined that there was a significant difference $(p=0.002)$ in the family psychiatric family questionnaire between the two matched groups in terms of age, gender and educational status and bipolar disorder in the family of $31 \%$ of the patient group. Neuropsychological test scores of patients was statistically lower than control group. Serum ADMA levels of patient group was statistically lower than control group $(\mathrm{p}=0.001)$. Statistically significant correlation was found between ADMA levels and spontaneous recall scores $(p=0.037)$, the percent of conceptual level responses $(p=0.029)$, including Stroop Test time scores $(p=0.043)$ and Trail Making Test A time score $(\mathrm{p}=0.002)$.

Conclusion: According to the results of present study, in patients with bipolar mood disorder, there is deterioration in areas of cognitive such as memory, learning, attention, processing speed, changing strategy and solving problem. It was determined that the impairment is not associated with serum NO level but the scores of spontaneous recall, the percent of conceptual level responses, time to complete the Stroop Test, Trail Making Test A time were determined that the relationship with serum ADMA level.

Keywords: Bipolar disorder; cognition; nitric oxide; asymmetric dimethylarginine.
\end{abstract}

Sorumlu Yazar / Corresponding Author: Betül KURTSES GÜRSOY, betulkurtses@yahoo.com

Geliş Tarihi/Received: 16.07.2018 Kabul Tarihi/Accepted: 25.10.2018 


\section{GíRiş}

Dünya Sağlık Örgütü (DSÖ) tarafindan işlevsellik kaybı açısından tüm tıbbi hastalıklar değerlendirildiğinde bipolar bozukluğun altıncı sırada bulunduğu belirtilmiştir (1). Bipolar bozukluk hastalarında işlevsellikteki bozulma, hastalık öncesi zayıf işlevsellik düzeyi, erken yaşta başlangıç, toplam hastalık süresi, eşik üstü ya da eşik altı depresif belirtiler, psikotik özellik taşıyan atakların yaşanması, hastaneye yatış sayısı, madde ya da alkol kullanımı, zayıf sosyal destek ve düşük sosyoekonomik düzey ile ilişkili bulunmuştur (2). Yapılan bir çalışmada işlevsellikte bozulmayı en iyi öngören klinik değişkenlerin eşik altı depresif belirtiler, daha önceki karma dönem sayısı, hastaneye yatış sayısı ve ileri yaşın olduğu belirtilmiştir (3).

Bipolar bozuklukta gözlenen bilişsel defisitlerin hastalığın klinik seyrine etkisi tam olarak bilinmemekle birlikte mesleki ve sosyal işlevsellikle birlikte yaşam kalitesi üzerine büyük etkisi olabileceği öngörülmektedir (4). Başka bir deyişle bipolar bozukluk tanılı hastalarda psikososyal alandaki işlevsellik yitiminin güçlü öngördürücülerinden biri de bilişsel bozukluklardır (5).

Son 20 yıla kadar, bipolar bozuklukta gözlenen bilişsel yeti yitimi hastalık dönemlerine özgü manik ve depresif belirtilere atfedilmekteydi (6). Fakat yapılan araştırmalarla hastalarda klinik belirtinin olmadığı ötimik dönemlerde de bilişsel bozuklukların devam ettiği kanıtlanmıştır (7-10).

Serbest radikal yapısında renksiz ve toksik bir gaz olan nitrik oksit (NO)'in santral sinir sistemi (SSS)'ndeki gelişimsel süreçte etkin bir rol oynamasına ek olarak ayrıca bipolar bozukluk, şizofreni, major depresyon, Alzheimer hastalığı, Hungtington hastalığı, alkol ve madde bağımlılığı, serebral iskemi ve inme gibi belli nöropsikiyatrik hastalıklarda da rol aldığı bilinmektedir (11). NO; noradrenalin ve dopamin salınımının düzenlenmesine ek olarak bu maddelerle etkileşir ve sinaptik aktarımda bu maddelerin işlevlerini değiştirir (12). Dolayısıyla hafiza, öğrenme, farkındalık, koku hassasiyeti ve yeme- içme davranışlarının da nitrik oksitten bağımsız olmadığı bilinmektedir (13).

Asimetrik dimetilarjinin (ADMA), L-arjininden NO sentezini sağlayan nitrik oksit sentetaz (NOS) enziminin endojen yarışmalı inhibitörüdür (14). Yapılan çalışmalar ADMA birikiminin NO sinyal iletim sisteminde önemli bir rolü olduğunu ve bunun beyindeki NO üretiminin çalış1labilmesi için yeni bir mekanizma sağladığını göstermiştir (15).

Bipolar hastalarda manik dönemde yapılan çalışmalarda sıklıkla NO seviyesinin sağliklı kontrollere göre yüksek olduğu görülmüştür $(13,16,17)$. Çalışmaların bulguları çelişkili olmakla birlikte ötimik ve depresif dönemlerdeki hastalarda da NO seviyesi yine artmış olarak tespit edilmiştir $(18,19)$. NO sentaz inhibitörü olan ADMA'nın ise bazı ruhsal bozuklukların patogenezindeki fonksiyonu araştırılmış ve Alzheimer hastalığı ve depresif bozuklukta seviyesinin artmış olduğu gösterilmiş $(20,21)$. Akut mani döneminde bulunan hastalarda yapılan bir çalışmada ise sağlkkl kontrollerle kıyaslandığında NO seviyesinde belirgin bir azalmaya ek olarak ADMA seviyesinde artı̧̧ olduğu gösterilmiştir (22).

Bu çalışmanın yapıldığı tarihte yapılan literatür taramasında ötimik dönemde ADMA düzeyinin ölçüldüğü herhangi bir bipolar bozukluk çalışmasına rastlanmamıştır. Ötimik dönemde bilişsel bozukluklar ile NO arasında kıyaslama yapılan bir çalışmada ise aralarında anlamlı ilişki olmadığ 1 vurgulanmıştır (23).

$\mathrm{Bu}$ çalışmada bilişsel yıkım ile öğrenme, hafiza ve dikkatte rol oynayan NO ve NOS inhibitörü ADMA arasındaki ilişkinin açığa çıkarılması hedeflenmiştir. Öncelikle bipolar bozukluk ötimik evrede olan hastaların sağlıklı kontrollere göre bilişsel işlevlerinin ve serum NO ve ADMA düzeylerinin karşılaştırılması, sonrasında muhtemel bilişsel yıkımla serum NO ve ADMA arasında ilişki olup olmadığının ortaya konulması amaçlanmıştır.

\section{GEREÇ VE YÖNTEMLER}

\section{Örneklem}

15.06.2014 - 15.12.2014 tarihleri arasında Afyon Kocatepe Üniversitesi Tıp Fakültesi Ruh Sağlığı ve Hastalıkları Anabilim Dalı Polikliniklerine ardı sıra başvuran ve DSM-5'e göre bipolar bozukluk tanısı almış olan, ayaktan tedavi görmekte olan 18-65 yaş arasındaki eğitim seviyesi en az ilkokul düzeyinde olan 45 hasta çalışmaya dahil edilmiştir. Bu çalışma için Afyon Kocatepe Üniversitesi Tıp Fakültesi Etik Komitesi'nin 12.06.2014 tarih ve 2014/09-171 sayılı kararı ile etik kurul onayı alınmıştır. Son 2 aydır remisyonda olan ve ölçekler uygulandığı esnada Hamilton Depresyon Derecelendirme Ölçeğinden 8 puan ve altı, Young Mani Derecelendirme Ölçeğinden 5 puan ve altı alan ve çalışma konusunda bilgilendirilen 83 hastadan dahil olma kriterlerini karşılamayan 34 hasta ve çalışmayı kabul etmeyen 4 hasta çalışma dışı bırakılmıştır. Örneklem seçilmeksizin hastalar çalışmaya dahil edilmiştir. Kontrol grubu ise hastane çalışanları, üniversite öğrencileri ve hasta yakınlarından seçilen 45 sağlıklı bireyden oluşturulmuş ve tüm katılımcılardan yazılı onam alınmıştır.

Tüm olgular için mental retardasyon, DSM-5'e göre bipolar bozukluk dışında psikiyatrik tanı almış olmak, ciddi organ yetmezliği, madde bağımlılığı (sigara içiciliği hariç), NOADMA düzeyini etkileyen ilaç kullanımı, aktif enfeksiyon, ciddi obezite, primer nörolojik bozukluklar, kronik kalp ve damar hastalıkları, hipertiroidi-hipotiroidi gibi endokrinopatik tanılar, son 6 ay içerisinde elektro konvulsif tedavi (EKT) almak, gebe olmak dışlanma kriteri olarak belirlenmiştir. Sonuç olarak çalışma hakkında bilgilendirilmiş ve onamı alınmış 45 ötimik hasta ve 45 sağlıklı kontrol çalışmaya dahil edilmiştir.

\section{Değerlendirme Araçları}

Sosyodemografik Veri Formu: Çalışmacılar tarafından çalışmanın özellikleri dikkate alınarak, çalışmaya katılan bireylerin sosyodemografik ve klinik özellikleri hakkında bilgi edinmek amacıyla oluşturulmuş bir formdur. Formda bireyin yaşı, medeni durumu, eğitimi, mesleği, birinci derece akrabalarında psikiyatrik hastalık öyküsü gibi maddeler bulunmaktadır. Ayrıca hasta grubu için hastalık başlama yaşı, hastalık süresi, geçirilmiş duygudurum dönemi sayısı ve tipi, hastaneye yatış sayısı, EKT ve intihar öyküsü ve ilaç kullanımı gibi maddelere de yer verilmiştir.

Young Mani Derecelendirme Ölçeği: Manik durumun şiddetini ölçmeye yönelik 1978 yılında Young ve ark. tarafindan geliştirilmiş olan Young-Mani Derecelendirme Ölçeği her biri 5 şiddet derecesi içeren 11 maddeden oluşmaktadır. Türkçe güvenilirlik ve geçerliliği ise Karadağ ve ark. (24) tarafından yapılmıștır.

Hamilton Depresyon Derecelendirme Ölçeği: Hastalardaki depresyonun şiddetini ölçmek için kullanılan, değerlendiricinin derecelemesine dayanan bir ölçektir. 1960 yılında Max Hamilton tarafından geliştirilmiş olan ölçeğin Türkçe güvenilirlik ve geçerliliği 1996 yılında Akdemir ve ark. (25) tarafından yapılmıştır.

Sözel Bellek Süreçleri Testi (SBST): SBST, anlık bellek, dikkat, bilginin kazanılması, saklama, hatırlama ve tanıma süreçleri hakkında bilgi verir. Kullanılmıs olan kelime listesi öğrenme testi olan Rey İşitsel Sözel Öğrenme Testi'nin Türkçe'ye uyarlanmış şeklidir, geçerlik ve güvenirlik çalışması Öktem (26) tarafından yapılmıştır.

Wisconsin Kart Eşleme Testi: İlk şekli 1948 yılında Berg tarafindan geliştirilmiş olan teste son şeklini Heaton 1981'de vermiştir (27). Amacı değişen çevresel uyaranlara yanıt olarak bilişsel stratejileri değiştirebilme yeteneğini ölçmek olan WKET'in BILLNOT Bataryası kapsamında standardizasyon çalışması yapılmıştır (28). Çalışmamızda testin bilgisayar versiyonu kullanılmıştır.

Stroop Testi: 1935 yilında Stroop (29) tarafindan deneysel olarak geliştirilmiş olan Stroop testinin çeşitli formları bulunmaktadır. $\mathrm{Bu}$ çalışmada ise Stroop testi TBAG (Temel Bilimler Araştırma Grubu) formu kullanılmıştır. 1999 yılında Karakaş ve ark. (30) tarafindan Türk toplumu için standardizasyon çalışmaları yapılmıştır.

İ Sürme A ve B Testleri: 1958'de Reitan (31) tarafindan geliştirilen dikkat hızını, mental esnekliği, görsel tarama ve motor hızı değerlendiren bu testin ilk bölümünde denek sayfa üzerinde gelişigüzel dağılmış rakamları 1'den başlayıp rakam 
sırası ile birleștirecektir; ikinci bölümünde ise kağıdın üzerinde hem rakamlar hem de alfabenin harfleri gelişigüzel dağılmıştır, burada 1'den A'ya, 2'den B'ye doğru bir rakam bir harf çizerek ilerlenir. Bunu düzgün yapabilmek için cevap eğilimini başarıyla bastırabilmek, yani bir rakamdan bir sonraki rakama ya da bir harften bir sonraki harfe geçmemek için kendini tutabilmek gerekir. B bölümünün aynı zamanda yürütücü işlevlerin bir göstergesi olduğu da bildirilmiştir (32). Bu çalışmada süre puanları değerlendirilmiştir.

Biyokimyasal Ölçüm İşlemleri: Çalışma için gerekli olan kan, katılımc1 bireylerden minimum 8 saatlik açlığı takiben sabah 08:00-12:00 saatleri arasında antekubital venden alınd. Alınan kanlardan $3220 \mathrm{~g}$ 'de $5 \mathrm{dk}$. santrifüj edilerek elde edilen serum örnekleri özel kutularda $-80 \mathrm{C}^{\circ}$ 'de saklandı. NO oksijen ile hızla reaksiyona girerek nitrit ve nitrata dönüştüğünden, nitrit üzerinden NO ölçümü yapıldı. $-80 \mathrm{C}^{\circ}$ de dondurularak bekletilen tüm örnekler Afyon Kocatepe Üniversitesi Tip Fakültesi Biyokimya Anabilim Dalı laboratuvarında serum NO düzeyi ve ADMA düzeyi çalışılmak üzere eş zamanlı çözdürülerek oda sıcaklığına getirildi. Özel kitlerin prospektüsüne uygun olarak çalışıldı.

\section{İstatistiksel Analiz}

Elde edilen verilerin tanımlayıcı istatistikleri hesaplandı. Kategorik verilerin gruplar arasında yüzde dağılımlarının karşılaştırılmasında Ki-Kare testi kullanıldı. Sürekli değişkenlerin normal dağılıma uygunluğu Shapiro-Wilk testi ile değerlendirildi ve parametrik test koşullarını sağlamadığı gözlendiğinden iki grup ortanca değerlerinin karşılaştırılmasında Mann-Whitney U testi kullanıldı. Sürekli değişkenler arasındaki korelasyon Spearman testi ile değerlendirildi. Veriler IBM SPSS 20.0 paket programı ile değerlendirilmiş olup $\mathrm{p}<0,05$ istatistiksel olarak anlamlı kabul edildi.

\section{BULGULAR}

\section{Sosyodemografik Veriler}

Hasta ve sağlıklı grupların ortalama yaşları sırasıyla 38,29 $\pm 12,04$

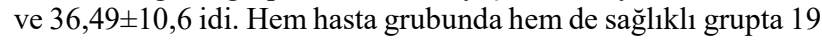
$(\% 42,2)$ kadın, $26(\% 57,8)$ erkek yer almaktaydı. Sağlıklı grupta $19(\% 42,2)$ kişi ilköğretim, $12(\% 26,7)$ kişi lise ve $14(\% 31,1)$ kişi üniversite mezunu iken, hasta grubunda $20(\% 44,4)$ kişi ilköğretim, $13(\% 28,9)$ kişi lise ve $12(\% 26,7)$ kişi üniversite mezunu idi. Sağlıklı grup ve hasta grubu arasında eğitim durumu, medeni durum, çalıșma durumu ve madde kullanımı öyküsünde istatistiki açıdan anlamlı farklılık olmadığı gözlendi. Hasta grubu ile kontrol grubu arasında ailevi psikiyatrik soygeçmiş sorgulamasında anlamlı derecede farklılık $(\mathrm{p}=0,002)$ olduğu ve hasta grubunun \%31,1'inin ailesinde bipolar bozukluk tanısına sahip bireylerin olduğu gözlendi.

Hasta grubundan alınan anamnez bilgileri doğrultusunda 29 $(\% 64,4)$ hastanın ilk duygudurum döneminin mani, $2(\% 4,4)$ hastanın hipomani, $13(\% 28,9)$ hastanın depresyon, $1(\% 2,2)$ hastanın karma dönem olduğu ve hastalığın ortalama başlangıç yaşının 24,44 $\pm 9,56$ olduğu gözlendi. Ayrıca hastaların $\% 48,8$ 'inin psikotik atak geçirmiş olduğu ve atak döneminde \%13,3'üne EKT uygulanmış olduğu tespit edildi. 37 (\%82,2) hasta tedaviye çoklu ilaç kullanımı ile devam ederken yalnız 8 $(\% 17,8)$ hasta tek ilaç-duygu durum düzenleyici (DDD) ile tedaviye devam etmekteydi. Çoklu ilaç kullanımı ile tedaviye devam eden 37 hastadan 26's1 $(\% 57,8)$ DDD ilaca ek olarak tek antipsikotik kullanırken, $11(\% 24,4)$ hasta DDD'ye ek olarak birden fazla antipsikotik kullanmaktayd.

\section{Nörokognitif Test Verileri}

Hasta ve kontrol grubunun sözel bellek süreçleri testi puanları birbiriyle kıyaslandığında anlık bellek, kritere ulaşma, en yüksek öğrenme, tutarsızlık puanı, kendiliğinden hatırlama, tanıma ve toplam hatırlama puanlarının istatistiksel açıdan anlamlı olarak farklı oldukları ve bu alanlarda hasta grubunun daha düşük performans gösterdikleri bulunmuştur (Tablo 1).

WKET puanlarına bakıldığında 13 puandan 9 tanesinde (toplam yanlış sayısı, toplam doğru sayısı, tamamlanan kategori sayısı, toplam perseveratif tepki sayıs1, toplam perseveratif hata sayıs1, toplam perseveratif olmayan hata sayıs1, perseveratif hata yüzdesi, ilk kategoriyi tamamlamada kullanılan tepki sayısı, kavramsal düzey tepki yüzdesi) bipolar bozukluk tanılı hastalar ile kontrol grubundaki sağlıklı bireyler arasında istatistiki açıdan anlamlı farklılı̆̆ın olduğu gözlenmiş̧ir. Bipolar bozukluk tanılı hastaların test performansının daha düşük olduğu saptanmıştır. Ötimik dönemde bulunan hastaların Stroop Testinin tüm bölümlerindeki (Bölüm1-5) süre puanlarının kontrol grubu ile kıyaslandığında istatistiki olarak anlamlı düzeyde $(\mathrm{p}<0,001)$ daha yüksek olduğu bulunmuştur. Ayrıca Bölüm 3, 4 ve 5'teki düzeltme sayıs1 $\left(\mathrm{p}_{3}=0,002, \mathrm{p}_{4}=0,002 \mathrm{p}_{5}<0,001\right)$ ile birlikte Bölüm 5 'te yapilan hata sayısının da $(\mathrm{p}=0,012)$ hasta grubunda anlaml olarak yüksek olduğu gözlenmiştir (Tablo 1).

$\underline{\text { Tablo 1. Nöropsikolojik test puanları }}$

\begin{tabular}{|c|c|c|c|c|c|c|c|c|}
\hline & & \multicolumn{3}{|c|}{ Hasta $(n=45)$} & \multicolumn{3}{|c|}{ Kontrol $(n=45)$} & \multirow[b]{2}{*}{$\mathbf{p}$} \\
\hline & & Ortanca & $\begin{array}{l}\text { En küçük } \\
\text { En büyük }\end{array}$ & $\begin{array}{l}\% 25 \\
\% 75\end{array}$ & Ortanca & $\begin{array}{l}\text { En küçük } \\
\text { En büyük }\end{array}$ & $\begin{array}{l}\% 25 \\
\% 75\end{array}$ & \\
\hline \multirow{12}{*}{ 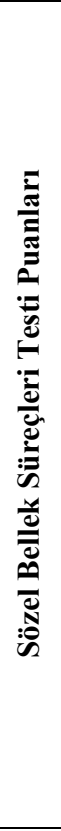 } & Anlık Bellek & 5,0 & $\begin{array}{l}2,0 \\
9,0 \\
\end{array}$ & $\begin{array}{l}4,0 \\
6,0 \\
\end{array}$ & 6,0 & $\begin{array}{c}3,0 \\
10,0 \\
\end{array}$ & $\begin{array}{l}5,0 \\
8,0 \\
\end{array}$ & $<0,001$ \\
\hline & Öğrenme Puanı & 93,5 & $\begin{array}{c}41,0 \\
136,0\end{array}$ & $\begin{array}{c}71,5 \\
112,0\end{array}$ & 120,0 & $\begin{array}{c}64,0 \\
144,0\end{array}$ & $\begin{array}{l}104,0 \\
131,0\end{array}$ & 0,458 \\
\hline & Kritere Ulaşma & 0,0 & $\begin{array}{c}0,0 \\
10,0\end{array}$ & $\begin{array}{l}0,0 \\
6,3\end{array}$ & 6,0 & $\begin{array}{c}0,0 \\
10,0\end{array}$ & $\begin{array}{l}3,5 \\
8,0\end{array}$ & $<0,001$ \\
\hline & En Yüksek Öğrenme & 12,0 & $\begin{array}{c}5,0 \\
15,0\end{array}$ & $\begin{array}{l}10,0 \\
15,0\end{array}$ & 15,0 & $\begin{array}{c}9,0 \\
15,0\end{array}$ & $\begin{array}{l}15,0 \\
15,0\end{array}$ & $<0,001$ \\
\hline & Öğrenme Yanlış Puanı & 9,5 & $\begin{array}{c}0,0 \\
33,0\end{array}$ & $\begin{array}{c}4,0 \\
16,0\end{array}$ & 7,0 & $\begin{array}{c}0,0 \\
24,0\end{array}$ & $\begin{array}{c}3,5 \\
11,0\end{array}$ & 0,142 \\
\hline & Perseverasyon & 0,0 & $\begin{array}{l}0,0 \\
7,0\end{array}$ & $\begin{array}{l}0,0 \\
1,3 \\
\end{array}$ & 0,0 & $\begin{array}{l}0,0 \\
6,0\end{array}$ & $\begin{array}{l}0,0 \\
1,0\end{array}$ & 0,396 \\
\hline & Tutarsızlık Puanı & 8,0 & $\begin{array}{c}1,0 \\
16,0\end{array}$ & $\begin{array}{l}4,0 \\
9,0\end{array}$ & 4,0 & $\begin{array}{c}0,0 \\
11,0\end{array}$ & $\begin{array}{l}1,0 \\
6,0\end{array}$ & $<0,001$ \\
\hline & Kendiliğinden Hatırlama & 9,0 & $\begin{array}{c}0,0 \\
15,0\end{array}$ & $\begin{array}{c}6,0 \\
13,0\end{array}$ & 13,0 & $\begin{array}{c}0,0 \\
15,0\end{array}$ & $\begin{array}{l}11,0 \\
14,0\end{array}$ & $<0,001$ \\
\hline & Tanıma & 4,0 & $\begin{array}{c}0,0 \\
17,0\end{array}$ & $\begin{array}{l}2,0 \\
6,3\end{array}$ & 1,0 & $\begin{array}{c}0,0 \\
14,0\end{array}$ & $\begin{array}{l}1,0 \\
3,5\end{array}$ & 0,001 \\
\hline & Toplam Hatırlama & 15,0 & $\begin{array}{c}7,0 \\
15,0\end{array}$ & $\begin{array}{l}13,0 \\
15,0\end{array}$ & 15,0 & $\begin{array}{l}14,0 \\
15,0\end{array}$ & $\begin{array}{l}14,0 \\
15,0\end{array}$ & $\mathbf{0 , 0 2 8}$ \\
\hline & Yanlış Hatırlama Puanı & 1,0 & $\begin{array}{l}0,0 \\
4,0\end{array}$ & $\begin{array}{l}0,0 \\
1,0 \\
\end{array}$ & 1,0 & $\begin{array}{l}0,0 \\
9,0 \\
\end{array}$ & $\begin{array}{l}0,0 \\
1,5 \\
\end{array}$ & 0,732 \\
\hline & Yanlış Tanıma & 0,0 & $\begin{array}{l}0,0 \\
6,0\end{array}$ & $\begin{array}{l}0,0 \\
1,0\end{array}$ & 0,0 & $\begin{array}{l}0,0 \\
3,0\end{array}$ & $\begin{array}{l}0,0 \\
1,0\end{array}$ & 0,334 \\
\hline
\end{tabular}


Tablo 1 (devam). Nöropsikolojik test puanları

\begin{tabular}{|c|c|c|c|c|c|c|c|c|}
\hline & \multicolumn{3}{|c|}{ Hasta $(n=45)$} & \multicolumn{3}{|c|}{ Kontrol $(n=45)$} & \multirow[b]{2}{*}{$\mathbf{p}$} \\
\hline & & Ortanca & $\begin{array}{l}\text { En küçük } \\
\text { En büyük }\end{array}$ & $\begin{array}{l}\% 25 \\
\% 75\end{array}$ & Ortanca & $\begin{array}{l}\text { En küçük } \\
\text { En büyük }\end{array}$ & $\begin{array}{l}\% 25 \\
\% 75\end{array}$ & \\
\hline \multirow{11}{*}{ 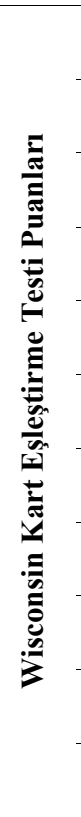 } & Toplam Yanlış Sayısı & 50,5 & $\begin{array}{l}20,0 \\
85,0\end{array}$ & $\begin{array}{l}39,8 \\
61,5\end{array}$ & 34,0 & $\begin{array}{l}19,0 \\
84,0\end{array}$ & $\begin{array}{l}27,0 \\
46,0\end{array}$ & $<0,001$ \\
\hline & Toplam Doğru Sayısı & 77,5 & $\begin{array}{c}43,0 \\
108,0\end{array}$ & $\begin{array}{l}66,5 \\
88,3\end{array}$ & 94,0 & $\begin{array}{c}44,0 \\
109,0\end{array}$ & $\begin{array}{c}82,0 \\
101,0\end{array}$ & $<0,001$ \\
\hline & Tamamlanan Kategori Sayısı & 3,0 & $\begin{array}{l}0,0 \\
9,0\end{array}$ & $\begin{array}{l}2,0 \\
5,0\end{array}$ & 6,0 & $\begin{array}{c}1,0 \\
10,0\end{array}$ & $\begin{array}{l}4,0 \\
8,0\end{array}$ & $<0,001$ \\
\hline & $\begin{array}{c}\text { Toplam Perseveratif Tepki } \\
\text { Sayıs } 1\end{array}$ & 29,0 & $\begin{array}{c}7,0 \\
69,0\end{array}$ & $\begin{array}{l}19,8 \\
45,0\end{array}$ & 19,0 & $\begin{array}{c}7,0 \\
75,0\end{array}$ & $\begin{array}{l}14,5 \\
25,5\end{array}$ & 0,002 \\
\hline & $\begin{array}{c}\text { Toplam Perseveratif Hata } \\
\text { Sayı1 }\end{array}$ & 24,5 & $\begin{array}{c}7,0 \\
58,0\end{array}$ & $\begin{array}{l}18,8 \\
36,3\end{array}$ & 19,0 & $\begin{array}{c}7,0 \\
63,0\end{array}$ & $\begin{array}{l}13,0 \\
23,0\end{array}$ & 0,003 \\
\hline & $\begin{array}{l}\text { Toplam Perseveratif } \\
\text { Olmavan Hata Sayı1 } 1\end{array}$ & 23,0 & $\begin{array}{l}10,0 \\
58,0\end{array}$ & $\begin{array}{l}15,0 \\
31,0\end{array}$ & 16,0 & $\begin{array}{c}8,0 \\
32,0\end{array}$ & $\begin{array}{l}12,0 \\
22,5\end{array}$ & $<0,001$ \\
\hline & Perseveratif Hata Yüzdesi & 1836,0 & $\begin{array}{c}125,0 \\
4531,0\end{array}$ & $\begin{array}{l}1386,5 \\
2656,0\end{array}$ & 1484,0 & $\begin{array}{c}125,0 \\
4922,0\end{array}$ & $\begin{array}{l}1016,0 \\
1797,0\end{array}$ & 0,003 \\
\hline & $\begin{array}{c}\text { İlk Kategoriyi Tamamlamada } \\
\text { Kullanılan Tepki Sayısı }\end{array}$ & 27,5 & $\begin{array}{c}0,0 \\
110,0\end{array}$ & $\begin{array}{l}12,8 \\
40,5\end{array}$ & 16,0 & $\begin{array}{c}10,0 \\
124,0\end{array}$ & $\begin{array}{l}12,0 \\
27,0\end{array}$ & 0,018 \\
\hline & $\begin{array}{c}\text { Kavramsal Düzey Tepki } \\
\text { Yüzdesi }\end{array}$ & 4336,0 & $\begin{array}{c}25,0 \\
8203,0\end{array}$ & $\begin{array}{l}2344,0 \\
5761,8\end{array}$ & 6484,0 & $\begin{array}{c}25,0 \\
8203,0\end{array}$ & $\begin{array}{l}5078,0 \\
7461,0\end{array}$ & $<\mathbf{0 , 0 0 1}$ \\
\hline & $\begin{array}{c}\text { Kurulumu Sürdürmede } \\
\text { Başarısızlık }\end{array}$ & 1,0 & $\begin{array}{l}0,0 \\
7,0\end{array}$ & $\begin{array}{l}0,0 \\
3,0\end{array}$ & 1,0 & $\begin{array}{l}0,0 \\
5,0\end{array}$ & $\begin{array}{l}1,0 \\
3,0\end{array}$ & 0,247 \\
\hline & Öğrenmeyi Öğrenme Puanı & $-33,0$ & $\begin{array}{c}-2962,0 \\
1268,0 \\
\end{array}$ & $\begin{array}{c}-643,3 \\
248,8\end{array}$ & $-63,0$ & $\begin{array}{c}-2350,0 \\
973,0\end{array}$ & $\begin{array}{c}-347,5 \\
273,0\end{array}$ & 0,769 \\
\hline \multirow{15}{*}{ 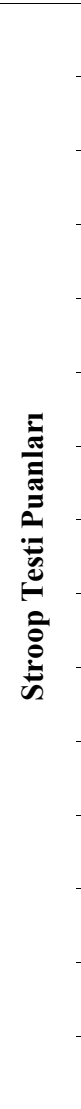 } & Bölüm 1 Süre (sn) & 11,0 & $\begin{array}{c}7,0 \\
22,0\end{array}$ & $\begin{array}{c}9,0 \\
13,0\end{array}$ & 8,0 & $\begin{array}{c}5,0 \\
17,0\end{array}$ & $\begin{array}{c}8,0 \\
10,0\end{array}$ & $<0,001$ \\
\hline & Bölüm 1 Hata Sayısı & 0,0 & $\begin{array}{l}0,0 \\
5,0\end{array}$ & $\begin{array}{l}0,0 \\
0,0\end{array}$ & 0,0 & $\begin{array}{l}0,0 \\
2,0\end{array}$ & $\begin{array}{l}0,0 \\
0,0\end{array}$ & 0,315 \\
\hline & Bölüm 1 Düzeltme Sayısı & 0,0 & $\begin{array}{l}0,0 \\
1,0\end{array}$ & $\begin{array}{l}0,0 \\
0,0\end{array}$ & 0,0 & $\begin{array}{l}0,0 \\
2,0\end{array}$ & $\begin{array}{l}0,0 \\
0,0\end{array}$ & 0,155 \\
\hline & Bölüm 2 Süre (sn) & 11,0 & $\begin{array}{c}6,0 \\
35,0\end{array}$ & $\begin{array}{c}9,0 \\
12,3\end{array}$ & 9,0 & $\begin{array}{c}5,0 \\
16,0\end{array}$ & $\begin{array}{c}8,0 \\
11,0\end{array}$ & $<\mathbf{0 , 0 0 1}$ \\
\hline & Bölüm 2 Hata Sayısı & 0,0 & $\begin{array}{l}0,0 \\
3,0\end{array}$ & $\begin{array}{l}0,0 \\
0,0\end{array}$ & 0,0 & $\begin{array}{l}0,0 \\
1,0\end{array}$ & $\begin{array}{l}0,0 \\
0,0\end{array}$ & 0,551 \\
\hline & Bölüm 2 Düzeltme Sayısı & 0,0 & $\begin{array}{l}0,0 \\
2,0\end{array}$ & $\begin{array}{l}0,0 \\
0,0\end{array}$ & 0,0 & $\begin{array}{l}0,0 \\
2,0\end{array}$ & $\begin{array}{l}0,0 \\
0,0\end{array}$ & 0,099 \\
\hline & Bölüm 3 Süre (sn) & 15,0 & $\begin{array}{l}10,0 \\
38,0\end{array}$ & $\begin{array}{l}13,0 \\
19,3\end{array}$ & 12,0 & $\begin{array}{c}7,0 \\
22,0\end{array}$ & $\begin{array}{l}11,0 \\
14,0\end{array}$ & $<\mathbf{0 , 0 0 1}$ \\
\hline & Bölüm 3 Hata Sayısı & 0,0 & $\begin{array}{l}0,0 \\
8,0\end{array}$ & $\begin{array}{l}0,0 \\
0,0\end{array}$ & 0,0 & $\begin{array}{l}0,0 \\
4,0\end{array}$ & $\begin{array}{l}0,0 \\
0,0\end{array}$ & 0,190 \\
\hline & Bölüm 3 Düzeltme Sayısı & 1,0 & $\begin{array}{l}0,0 \\
6,0\end{array}$ & $\begin{array}{l}0,0 \\
2,0\end{array}$ & 0,0 & $\begin{array}{l}0,0 \\
2,0\end{array}$ & $\begin{array}{l}0,0 \\
1,0\end{array}$ & 0,002 \\
\hline & Bölüm 4 Süre (sn) & 22,5 & $\begin{array}{l}13,0 \\
70,0\end{array}$ & $\begin{array}{l}19,0 \\
27,5\end{array}$ & 17,0 & $\begin{array}{l}10,0 \\
44,0\end{array}$ & $\begin{array}{l}13,0 \\
22,5\end{array}$ & $<0,001$ \\
\hline & Bölüm 4 Hata Sayısı & 0,0 & $\begin{array}{l}0,0 \\
3,0\end{array}$ & $\begin{array}{l}0,0 \\
0,0\end{array}$ & 0,0 & $\begin{array}{l}0,0 \\
1,0\end{array}$ & $\begin{array}{l}0,0 \\
0,0\end{array}$ & 0,073 \\
\hline & Bölüm 4 Düzeltme Sayısı & 1,0 & $\begin{array}{l}0,0 \\
6,0\end{array}$ & $\begin{array}{l}0,0 \\
3,0\end{array}$ & 0,0 & $\begin{array}{l}0,0 \\
4,0\end{array}$ & $\begin{array}{l}0,0 \\
10\end{array}$ & 0,002 \\
\hline & Bölüm 5 Süre (sn) & 35,0 & $\begin{array}{l}21,0 \\
77,0\end{array}$ & $\begin{array}{l}27,0 \\
42,3\end{array}$ & 25,0 & $\begin{array}{l}10,0 \\
64,0\end{array}$ & $\begin{array}{l}19,0 \\
30,5\end{array}$ & $<\mathbf{0 , 0 0 1}$ \\
\hline & Bölüm 5 Hata Sayısı & 1,0 & $\begin{array}{l}0,0 \\
7,0\end{array}$ & $\begin{array}{l}0,0 \\
3,3\end{array}$ & 0,0 & $\begin{array}{c}0,0 \\
12,0\end{array}$ & $\begin{array}{l}0,0 \\
2,0\end{array}$ & 0,012 \\
\hline & Bölüm 5 Düzeltme Sayısı & 3,0 & $\begin{array}{l}0,0 \\
9,0\end{array}$ & $\begin{array}{l}1,0 \\
4,0\end{array}$ & 1,0 & $\begin{array}{l}0,0 \\
4,0\end{array}$ & $\begin{array}{l}0,0 \\
2,0\end{array}$ & $<0,001$ \\
\hline \multirow{2}{*}{ 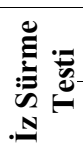 } & İz Sürme A Testi Süresi (sn) & 57,0 & $\begin{array}{c}18,0 \\
175,0\end{array}$ & $\begin{array}{l}39,3 \\
86,5\end{array}$ & 37,0 & $\begin{array}{c}14,0 \\
108,0\end{array}$ & $\begin{array}{l}25,0 \\
52,0\end{array}$ & $<0,001$ \\
\hline & İz Sürme B Testi Süresi (sn) & 191,0 & $\begin{array}{c}34,0 \\
646,0\end{array}$ & $\begin{array}{l}111,8 \\
295,0\end{array}$ & 98,0 & $\begin{array}{c}41,0 \\
330,0\end{array}$ & $\begin{array}{c}67,5 \\
128,0\end{array}$ & $<\mathbf{0 , 0 0 1}$ \\
\hline
\end{tabular}

Karmaşık dikkat, mental esneklik ve yürütücü işlevlere duyarlı olan İz Sürme Testi A ve B puanlarına bakıldığında hastaların kontrol grubuna göre istatistiki olarak anlamlı derecede $(\mathrm{p}<0,001)$ daha düşük performans sergiledikleri görülmektedir (Tablo 1).

Hasta grubunun klinik özellikleri ile SBST puanları arasındaki ilişkiye bakıldığında; hastalık süresi arttıkça en yüksek öğrenme ve kendiliğinden hatırlama puanlarında belirgin bir düşüklüğün olduğu belirlenmiştir (Tablo 2).

Geçirilen duygudurum dönemleri içinde ise mani dönemi sayısı arttıkça SBST'nin 4 puanında da düşme yaşandığı ve bu düşmenin istatistiki açıdan anlamlı olduğu görülmüştür. Yine geçirilen depresif dönem sayısının artması ile en yüksek 
öğrenme, kendiliğinden hatırlama ve toplam hatırlama puanlarında düşme olduğu ve bu performans düşüklüğün istatistiki olarak anlamlı olduğu bulunmuştur (Tablo 2).

\section{Biyokimyasal Analiz Verileri}

Hasta ve kontrol grubu serum NO düzeyleri açısından karşılaştırıldığında ise istatistiki olarak anlamlı bir farkın olmadığ1 görülmüştür $(\mathrm{p}=0,458)$. Bipolar bozukluk grubundaki hastalarla sağlıklı kontroller serum ADMA düzeyleri açısından karşılaştırıldığında ise iki grup arasında istatistiki olarak anlamlı sayılacak derecede farklılığın olduğu $(p=0,001)$ ve hasta grubunda kan düzeyi ortalamasının daha düşük olduğu gözlenmiştir (Tablo 3).

Test verileri ile serum NO düzeyi karşılaştırmasında herhangi anlamlı ilişki olmadığı görüldü. Serum ADMA düzeyi ile bazı puanlar arasında ise istatistiki olarak anlamlı sayılacak ilişki olduğu tespit edildi. Bu puanlar; SBST testindeki kendiliğinden hatırlama puanı, WKET testindeki kavramsal düzey tepki yüzdesi, Stroop Testindeki süre puanı, İz Sürme testinde ise A formunu tamamlama süresidir (Tablo 4).

\section{TARTIŞMA}

Mevcut çalışma, bipolar bozukluk tanılı hastalarda nörobilişsel işlev yıkımı ile serum NO ve ADMA arasındaki ilişkiyi inceleyen ilk çalışmalardan biri olma özelliğini taşımaktadır. Yapılan bu çalışmada ötimik dönemde bilişsel defísitlerin devam ettiği gözlenmiş olup, bu defisitlerin özellikle sözel bellek, problem çözme, seçici dikkati sürdürme, tepki değiştirme alanlarında daha belirgin olduğu tespit edilmiştir. Ayrica hasta grubunda kan ADMA düzeyi daha düşük bulunmuş olup bu düşüklüğün bilişsel işlev kaybında bir öngördürücü olmadığı sonucuna varılmıştır. Ötimik dönemdeki bipolar bozukluk hastalarıyla yapılan çalıșmalarda bilişsel bozukluklardaki en tutarlı sonuçlar sözel bellekle ilgili testlerden elde edilmiştir (33-36). Sözel bellek süreçleri ile ilgili testlerin temporal korteks işlevi hakkında bilgi verdiği ileri sürülmektedir (37). Yapılan bir çalışmada ötimik hastalarda sözel bellekte işlevsellik kaybı olduğu, kısa süreli gecikmiş hatırlama ve uzun süreli gecikmiş hatırlama performansının sağlıklı bireylere göre daha düşük seyrettiği bulunmuștur (38). Torres ve ark. (39) tarafindan hazırlanan meta analizde ise ötimik hasta grubu ile sağlıklı bireyler arasında dikkat/işlem hızı ve anlık bellek puanları arasında orta-yüksek etki aralığında fark olduğu bulunmuştur. Bizim çalışmamızda da benzer olarak Sözel Bellek Süreçleri Testinde anlık bellek, kritere ulaşma, en yüksek öğrenme, tutarsızlık puan1, kendiliğinden hatırlama, tanıma ve toplam hatırlama puanlarının bipolar bozukluk hastalarında istatistiki olarak anlamlı derecede düşük olduğu bulunmuştur.

Sözel Bellek Süreçleri testinde bulunan anlık bellek, kritere ulaşma ve en yüksek öğrenme puanlarındaki düşüklük hastanın bilgiyi öğrenmede ve belleğe kayıt etmekte sorun yaşadığını göstermektedir. Yine aynı testte bulunan tutarsızlı puanındaki yükseklik ise bir stratejiyi terk edip başka bir stratejiye geçmede yani hastanın öğrenme stratejisini sürdürmede güçlük çektiğini, organizasyondan yoksun bir öğrenme biçimi olduğunu göstermektedir (26). Hasta grubunda kendiliğinden hatırlama, tanıma ve toplam hatırlama puanlarının da düşük olduğu gözlenmiş ve bu da anlık bellekten uzun süreli belleğe bilgi transferinde ve kayıt edilen ya da öğrenilen bilginin uzun süreli bellekten geri çağırılmasında işlevsellik kaybı olması ile yorumlanmıştır. Bu durumda hastanın bu kaybı dengeleyebilmesi için bir bilgiyi öğrenmesi, uzun süreli belleğe aktarması ve gerektiğinde geri çağırabilmesi için sağlıklı bireylere göre bilgiyi daha fazla sayıda tekrar etmesi gerekmektedir.

Çalışmadaki WKET puanlarından tamamlanan kategori sayısındaki düşüklük bipolar hastalarda kavram oluşturmadaki eksikliğe dikkat çekmektedir. Yani hastalar testin altta yatan kavramsal işleyişini anlamada zorluk çekmişlerdir. Perseveratif hataların sayısındaki fazlalık da öğrenilmiş yanıtı durdurmada sorun olduğunu göstermektedir. Hem perseveratif hata sayısının hem de perseveratif olmayan hata sayısının fazlalığı ise hastaların strateji geliştirememesi ve bilişsel esnekliğin azalması ile yorumlanmıștır.

Literatür taramasında yapılan birçok çalışmada bipolar ötimik hastaların, bölünmüş dikkati ve prepotent tepkiyi inhibe etme yeteneğini ölçen Stroop Testinde sağliklı kontrollere göre daha düşük performans sergiledikleri gözlenmiştir (33,40-43). Yapılan bu çalışmada da hastaların Stroop Testindeki tüm bölümleri tamamlama sürelerinin daha uzun olduğu, bölüm 3 'ten itibaren diğer bölümlerde düzeltme sayısının arttığı, bölüm 5 de ise yapılan hata sayısının sağlıklı kontrollere kıyasla anlamlı olarak daha fazla olduğu ortaya konulmuştur. Test sonucunda bipolar hastaların karmaşık problemleri çözme, tepki değiştirme, seçici dikkati sürdürme, bozucu etki altında algısal kurulumu devam ettirme yeteneklerinde zayıflama olduğu bu yüzden işlemi tamamlama konusunda daha çok zamana ihtiyaç duydukları ve daha fazla yanlış yaptıkları gözlenmiştir.

Tablo 2. Hasta grubunda klinik değişkenler ile SBST puanlarının karşılaştırılması

\begin{tabular}{|c|c|c|c|c|c|c|c|}
\hline & & \multirow{2}{*}{$\begin{array}{c}\text { Hastalık } \\
\text { Başlama Yaşı }\end{array}$} & \multirow{2}{*}{$\begin{array}{c}\text { Hastalık } \\
\text { Süresi }\end{array}$} & \multicolumn{4}{|c|}{ Geçirilen Atak Sayısı* } \\
\hline & & & & Mani & Hipomani & Depresyon & Karma \\
\hline \multirow{2}{*}{ Anlık bellek } & $\mathrm{r}$ & $-0,073$ & $-0,269$ & $-0,307$ & $-0,026$ & $-0,271$ & $-0,021$ \\
\hline & $\mathrm{p}$ & 0,632 & 0,074 & 0,040 & 0,867 & 0,072 & 0,891 \\
\hline \multirow{2}{*}{ En Yüksek Öğrenme } & $\mathrm{r}$ & $-0,390$ & $-0,446$ & $-0,428$ & 0,280 & $-0,390$ & $-0,087$ \\
\hline & $\mathrm{p}$ & 0,800 & $\mathbf{0 , 0 0 2}$ & $\mathbf{0 , 0 0 3}$ & 0,856 & $\mathbf{0 , 0 0 8}$ & 0,570 \\
\hline \multirow{2}{*}{ Kendiliğinden Hatırlama } & $\mathrm{r}$ & $-0,008$ & $-0,412$ & $-0,448$ & $-0,111$ & $-0,466$ & $-0,176$ \\
\hline & $\mathrm{p}$ & 0,959 & 0,005 & 0,002 & 0,467 & $\mathbf{0 , 0 0 1}$ & 0,249 \\
\hline \multirow{2}{*}{ Toplam Hatırlama } & $\mathrm{r}$ & $-0,189$ & $-0,350$ & $-0,480$ & $-0,046$ & $-0,401$ & $-0,313$ \\
\hline & $\mathrm{p}$ & 0,213 & 0,018 & $\mathbf{0 , 0 0 1}$ & 0,763 & 0,006 & $\mathbf{0 , 0 3 7}$ \\
\hline
\end{tabular}

SBST: Sözel Bellek Süreçleri Testi, *: Hastaların yașam boyu toplam geçirdikleri atak sayıları

Tablo 3. Serum nitrik oksit ve asimetrik dimetilarjinin düzeyleri

\begin{tabular}{|c|c|c|c|c|c|c|c|}
\hline & \multicolumn{3}{|c|}{ Hasta $(n=45)$} & \multicolumn{3}{|c|}{ Kontrol $(n=45)$} & \multirow[b]{2}{*}{$\mathbf{p}$} \\
\hline & Ortanca & $\begin{array}{l}\text { En küçük } \\
\text { En büyük }\end{array}$ & $\begin{array}{l}\% 25 \\
\% 75 \\
\end{array}$ & Ortanca & $\begin{array}{l}\text { En küçük } \\
\text { En büyükk }\end{array}$ & $\begin{array}{l}\% 25 \\
\% 75 \\
\end{array}$ & \\
\hline Nitrik Oksit & 1,54 & $\begin{array}{c}0,48 \\
10,71\end{array}$ & $\begin{array}{l}1,09 \\
2,12\end{array}$ & 1,31 & $\begin{array}{l}0,33 \\
4,30\end{array}$ & $\begin{array}{l}0,96 \\
2,60\end{array}$ & 0,458 \\
\hline Asimetrik Dimetilarjinin & 0,42 & $\begin{array}{l}0,00 \\
3,68\end{array}$ & $\begin{array}{l}0,34 \\
0,46\end{array}$ & 0,48 & $\begin{array}{l}0,08 \\
5,02\end{array}$ & $\begin{array}{l}0,43 \\
1,53\end{array}$ & 0,001 \\
\hline
\end{tabular}


Tablo 4. Nörokognitif test puanları ile serum nitrik oksit ve asimetrik dimetilarjinin düzeyleri arasındaki ilişki

\begin{tabular}{|c|c|c|c|}
\hline & & $\begin{array}{l}\text { Nitrik } \\
\text { Oksit }\end{array}$ & $\begin{array}{c}\text { Asimetrik } \\
\text { Dimetilarjinin }\end{array}$ \\
\hline \multicolumn{4}{|l|}{ Sözel Bellek Süreçleri Testi } \\
\hline \multirow{2}{*}{ Anlık Bellek } & $\mathrm{r}$ & 0,040 & 0,011 \\
\hline & $\mathrm{p}$ & 0,707 & 0,945 \\
\hline \multirow{2}{*}{ Kritere Ulaşma } & $\mathrm{r}$ & 0,049 & 0,086 \\
\hline & $\mathrm{p}$ & 0,645 & 0,423 \\
\hline \multirow{2}{*}{ En Yüksek Öğrenme } & $\mathrm{r}$ & $-0,017$ & 0,118 \\
\hline & $\mathrm{p}$ & 0,873 & 0,269 \\
\hline \multirow{2}{*}{ Tutarsızlık Puanı } & $\mathrm{r}$ & 0,133 & 0,175 \\
\hline & $\mathrm{p}$ & 0,212 & 0,250 \\
\hline \multirow{2}{*}{ Kendiliğinden Hatırlama } & $\mathrm{r}$ & $-0,006$ & 0,221 \\
\hline & $\mathrm{p}$ & 0,958 & $\mathbf{0 , 0 3 7}$ \\
\hline \multirow{2}{*}{ Tanıma } & $\mathrm{r}$ & $-0,048$ & $-0,005$ \\
\hline & $\mathrm{p}$ & 0,652 & 0,973 \\
\hline \multirow{2}{*}{ Toplam Hatırlama } & $\mathrm{r}$ & $-0,048$ & 0,129 \\
\hline & $\mathrm{p}$ & 0,653 & 0,400 \\
\hline \multicolumn{4}{|l|}{ Wisconsin Kart Eşleştirme Testi } \\
\hline \multirow{2}{*}{ Toplam Yanlış Sayısı } & $\mathrm{r}$ & 0,113 & $-0,029$ \\
\hline & $\mathrm{p}$ & 0,288 & 0,851 \\
\hline \multirow{2}{*}{ Toplam Doğru Sayısı } & $\mathrm{r}$ & 0,113 & $-0,029$ \\
\hline & $\mathrm{p}$ & 0,288 & 0,851 \\
\hline \multirow{2}{*}{ Tamamlanan Kategori Sayısı } & $\mathrm{r}$ & $-0,046$ & $-0,088$ \\
\hline & $\mathrm{p}$ & 0,664 & 0,567 \\
\hline \multirow{2}{*}{$\begin{array}{l}\text { Toplam Perseveratif Hata } \\
\text { Sayıs } 1\end{array}$} & $\mathrm{r}$ & 0,125 & $-0,035$ \\
\hline & $\mathrm{p}$ & 0,241 & 0,818 \\
\hline \multirow{2}{*}{$\begin{array}{c}\text { Toplam Perseveratif Olmayan } \\
\text { Hata Sayıs }\end{array}$} & $\mathrm{r}$ & 0,050 & $-0,005$ \\
\hline & $\mathrm{p}$ & 0,637 & 0,972 \\
\hline \multirow{2}{*}{ Perseveratif Hata Yüzdesi } & $\mathrm{r}$ & 0,125 & $-0,035$ \\
\hline & $\mathrm{p}$ & 0,241 & 0,818 \\
\hline \multirow{2}{*}{$\begin{array}{c}\text { İlk Kategoriyi Tamamlamada } \\
\text { Kullanılan Tepki }\end{array}$} & $\mathrm{r}$ & 0,011 & $-0,122$ \\
\hline & $\mathrm{p}$ & 0,915 & 0,255 \\
\hline \multirow{2}{*}{$\begin{array}{c}\text { Kavramsal Düzey Tepki } \\
\text { Yüzdesi }\end{array}$} & $\mathrm{r}$ & $-0,108$ & 0,230 \\
\hline & $\mathrm{p}$ & 0,313 & 0,029 \\
\hline \multicolumn{4}{|l|}{ Stroop Testi } \\
\hline \multirow{2}{*}{ Bölüm 5 Süre } & $\mathrm{r}$ & 0,092 & $-0,214$ \\
\hline & $\mathrm{p}$ & 0,391 & 0,043 \\
\hline \multirow{2}{*}{ Bölüm 5 Hata } & $\mathrm{r}$ & $-0,137$ & $-0,127$ \\
\hline & $\mathrm{p}$ & 0,198 & 0,233 \\
\hline \multirow{2}{*}{ Bölüm 5 Düzeltme } & $\mathrm{r}$ & 0,141 & $-0,124$ \\
\hline & $\mathrm{p}$ & 0,184 & 0,243 \\
\hline \multicolumn{4}{|l|}{ İz Sürme Testleri } \\
\hline \multirow{2}{*}{ İz Sürme A } & $\mathrm{r}$ & $-0,078$ & 0,327 \\
\hline & $\mathrm{p}$ & 0,468 & 0,002 \\
\hline \multirow{2}{*}{ İz Sürme B } & $r$ & 0,016 & $-0,142$ \\
\hline & $\mathrm{p}$ & 0,883 & 0,182 \\
\hline
\end{tabular}

Görsel-mekansal algılama, sürekli dikkat, görsel tarama, mekansal ihmal ve tepki hızını ölçen İz Sürme Testi, Martinez Aran ve ark. (38) tarafından yapılan çalışmada kullanılmış olup ötimik hastaların sağlıklı kontrollere göre daha düşük performans sergiledikleri ve özellikle A Testindeki performans düşüklüğünün daha belirgin olduğu ortaya konulmuştur. Ötimik hastaların sağlıklı kontrollerle bilişsel işlevlerinin karşılaştırıldığı başka bir çalışmada ise İz Sürme A ve B testlerinde istatistiki açıdan anlamlı farklılığın olduğu ve bu farklılığın psikososyal fonksiyonlarla korele olduğu gözlenmiştir (44). Yapılan bu çalışmada da İz Sürme A testindeki veriler hastalardan beklenen psikomotor retardasyon halinin göstergesi olarak yorumlansa bile B testindeki farkl1lık set değiştirme ve yaygın tepkiyi ketleme konusunda göze çarpan bir eksiklik olduğunu kanıtlamaktadır.
Sonuç olarak çalışmamızdaki nöropsikolojik test verilerine bakıldığında ötimik hastalarda temporal korteks, frontal alan, dorsolateral prefrontal korteks ve orbitofrontal korteks ișlevleri hakkında bilgi veren SBST, WKET, Stroop Testleri ve İz Sürme Testinde performanslar açısından ötimik hasta ve sağlıklı bireyler arasında belirgin fark olduğu tespit edilmiştir.

$\mathrm{Bu}$ bulgular 1şığında hastaların ötimik dönemde öğrenme, uzun süreli belleğe transfer, uzun süreli bellekten bilgi çağırma, dikkati sürdürme, seçici dikkati devam ettirme, strateji değiştirme, bozucu etkiye direnç gösterme, planlama, problem çözme, hızlı tepki verme gibi yeteneklerinde kısıtl1lık olduğu gözlenmiştir. Bilişsel işlev kısıtlılığı sosyodemografik ve klinik değişkenlerle birlikte değerlendirildiğinde ise farklı sonuçlar göze çarpmaktadır. Hastalığın erken yaşta başlaması ve hastalık süresinin uzun olması ile nörobilisssel defisitin arttığını ileri süren çalışmalar mevcuttur (45-46). Bora ve ark. (47) tarafindan yapılan çalışmada erken başlangıç yaşının özellikle sözel bellekle ilgili yeti yitimini etkilediği öne sürülmüştür. Bazı çalışmalarda mani dönemi sayısı ile sözel bellek performansının ters korele olduğu hatta öğrenme performansının hatırlama performansına göre daha kötü seyretmesine rağmen mani dönemi sayısının hatırlama, geri çağırma yeteneğini daha çok etkilediği ileri sürülmüştür $(9,38,48)$. Depresif dönem sayısı ile bilişsel işlevler arasındaki korelasyon mani dönemi kadar fazla incelenmemiş olsa da yapılan çalışmalar depresif dönem sayısı ile yürütücü işlevler $(40,41)$, sözel bellek (49) ve psikomotor hız (47) arasında ilişki olduğunu ortaya koymuştur. Nehra ve ark. (50) tarafindan yapılan çalışmada ise ötimik hastalar kendi içlerinde tek duygudurum dönemi geçirenler ve birden çok duygudurumu dönemi geçirenler olarak ikiye ayrılmış ve sağlıkl bireylerle kıyaslanmıştır. Sonuç olarak sağlıklı bireylere göre her iki grupta da yıkım olmasına karşın duygudurum dönem sayısının bu yıkımı etkilemediği ileri sürülmüştür.

Çalışmamızda yaptığımız nöropsikolojik testlerin verilerini hastaların klinik özelliklerine göre irdelediğimizde en anlamlı verilerin SBST puanlarında olduğu gözlemlendi. Hastalık başlama yaşı ile kıyaslandığında herhangi istatistiki anlamlılı̆̆ın olmadığı, fakat hastalık süresi ile uzun süreli belleği yansıtan kendiliğinden hatırlama puanının ters korele olduğu görüldü. $\mathrm{Bu}$ durum hastalık süresi arttıkça depodan bilgiyi geri çağırma yetisinin azaldığ 1 șeklinde yorumlanmıștır.

Duygudurum dönemi geçirme sayısına bakıldığında ise en anlamlı verilerin mani dönemi geçirme sayısı ile anlık bellek, en yüksek öğrenme, kendiliğinden hatırlama ve toplam hatırlama puanları arasında olduğu ve aralarında ters korelasyon olduğu gözlemlendi. Yine geçirilmiş depresif dönem sayısı ile en yüksek öğrenme, kendiliğinden hatırlama ve toplam hatırlama puanları arasında istatistiki olarak anlamlı ters korele bir ilişki olduğu fakat aynı ilişkinin anlık bellek puanında olmadığg gözlendi. Bu da daha önceki çalışmalara benzer olarak mani dönemi sayısının ve depresif dönem sayısının her ikisinin de sözel belleği belirgin olarak etkilediği ve bu etkilemenin depresif dönemde mani dönemi kadar etkin olmadığı şeklinde yorumlanmıştır. Hipomani ve karma dönem sayıları ile test verileri arasında ilişkinin bulunamaması hasta grubunda genel olarak hipomani ve karma dönemi geçirenlerin sayısının az olmasından kaynaklanabileceği düşünülmüştür. Klinik değiş̧kenler ile WKET, Stroop Testleri ve İz Sürme Testleri puanları arasında anlamlı bir ilişki saptanmamış olup bu durum örneklem sayısının düşüklüğüne bağlanmıştır.

Yapılan çalışmalarda NO'nun öğrenme ve hafiza ile ilgili süreçleri de içeren birçok nöronal fonksiyonda, kortikal uyarılmada, gıda alımında, esnemede, penil ereksiyonunda, damar dilatasyonunda ve immün cevapta rolü olduğu görülmüştür (51). Ayrıca NOS enzim inhibitörü olan ADMA ile yapılan bir çalışmada Alzheimer hastalarında ADMA'nın arttığ 1 ve dolayısıyla NO'nun azaldığı görülmüştür. NO düzeyindeki azalmanın, bilişsel işlev kaybını arttırdığı düşünülmüştür (52). Ayrica bir oksidatif stres belirteci olan NO ile bipolar bozukluğun çeşitli fazlarında bulunan hastalarla çalışmalar 
yapılmış ve çelişkili sonuçlar elde edilmiştir. Savaş ve ark. (13) tarafindan ve Gergerlioğlu ve ark. (16) tarafindan yapılan çalışmalarda manik fazda bulunan hastalarda NO seviyesi yüksek gözlenirken, depresif dönemdeki olgularda ve ötimik olan olgularda da NO seviyesinin yüksek seyrettiğini ortaya koyan çalışmalar bulunmaktadır $(18,19)$. Hoekstra ve ark. (53) tarafindan yapılan bir çalışmada ise manik dönemde bulunan hastalar ve sağlıklı kontroller kıyaslandığında NO düzeyinin hasta grubunda daha düşük olduğu bulunmuştur. Yine manik fazda bulunan hastalarla yapılan başka bir çalışmada ise hasta grubunda ADMA düzeyinin sağlıklı kontrollere kıyasla daha yüksek NO düzeyinin ise daha düşük olduğu bulunmuştur (22). Oksidatif stres parametreleri ile yapılan bu çalışmalardaki çelişkilerde ilaç kullanımının, ek hastalık varlığının, diyetin ve sigara içiminin rol oynayabileceği ileri sürülmüştür (54).

Bizim yaptığımız çalışmada hasta grubu ile kontrol grubu arasında NO düzeyleri açısından istatistiki anlamda bir farklılık gözlenmezken ADMA düzeylerinde farklılık olduğu ve hasta grubunda ADMA düzeyinin kontrol grubuna daha düşük düzeylerde seyrettiği bulunmuştur. Bunun sonucu olarak genel ortalamada yine hasta grubunun NO düzeyi ortalamasının kontrol grubuna göre daha yüksek olduğu fakat bunun her iki grup arasında istatistiksel anlamı olmadığ saptandı.

Sonuç olarak yapılan çalışmada nöropsikolojik test verileri ile NO ve ADMA düzeyleri kıyaslandığında ise NO ile anlamlı hiçbir ilişki gözlenmezken ADMA düzeyleri ile testlerin alt puanları (SBST puanları içinden kendiliğinden hatırlama puanı ile, WKET puanları içinden kavramsal düzey tepki yüzdesi ile, Stroop Test süre puanları, İz Sürme A testi süre puanı) arasında anlamlı ilişki olduğu bulunmuştur. Fakat bu ilişki ADMA'nın bilişsel işlev öngördürücüsü olması konusunda yetersiz kalmıştır. Bipolar bozukluk tanılı hastalarda bilișsel işlevlerin $\mathrm{NO}$ ve ADMA ile ilişkisi daha önce yeterince tartışılmayan bir konudur. $\mathrm{Bu}$ çalışmada bipolar bozukluk tanılı hastalarda sağlıklı kontrollere kıyasla ADMA düzeyinin daha düşük, bilişsel defisitin daha fazla olduğu gözlenmiştir. Geniş katılımcı sayısı ve nöropsikolojik test profilleri ile yapılacak ileriki çalışmalardan beklenen, aradaki olası ilişkinin kanıtlanması ile klinisyenlere bilişsel işlev bozukluklarını biyobelirteçler ile takip olanağı sunmasidir.

\section{KISITLILIKLAR}

Çalışmanın kesitsel bir çalışma olması, hasta sayısının az olması hastalara uygulanacak olan testlerin süresinin optimumda tutulması açısından görsel uzamsal bellek ve sosyal bilişsel işlevler gibi bazı nörobilişsel değerlendirmelerin çalışmaya dahil edilmemesi çalışmanın kısıtlılıklarındandır. Ayrıca bilişsel işlevler üzerinde etkisi olduğu düşünülen ilaç kullanımının dışlanmaması, ötimik dönemde bulunma kıstasının en az 2 ay olarak belirlenmesi ve çalışmaya alınan hastaların 18-65 yaş aralığı gibi geniş bir aralıkta olması yine bu çalışmanın önemli kısıtlılıklarından biridir.

\section{TEŞEKKÜR}

$\mathrm{Bu}$ çalı̧̧ma Afyon Kocatepe Üniversitesi Bilimsel Araştırma Projeleri Koordinasyon Birimi tarafindan 14.TUS.08 proje numarası ile desteklenmiştir.

\section{KAYNAKLAR}

1. Akiskal HS. Duygudurum bozuklukları: Klinik özellikler. In: Sadock BJ, Sadock VA, eds. (Aydın H, Bozkurt A, çeviri ed). Türkçe: Kaplan \& Sadock's Comprehensive Textbook of Psychiatry. 8th ed. Ankara: Güneş kitabevi; 2007. p.1611-52.

2. Huxley N, Baldessarini RJ. Disability and its treatment in bipolar disorder patients. Bipolar Disord. 2007;9(1-2):18396.

3. Rosa AR, Reinares M, Franco C, Comes M, Torrent C, Sánchez-Moreno J, et al. Clinical predictors of functional outcome of bipolar patients in remission. Bipolar Disord. 2009;11(4):401-9.
4. Baune BT, Li X, Beblo T. Short- and long-term relationships between neurocognitive performance and general function in bipolar disorder. J Clin Exp Neuropsychol. 2013;35(7):75974.

5. Sanchez-Moreno J, Martinez-Aran A, Tabarés-Seisdedos R, Torrent C, Vieta E, Ayuso-Mateos JL. Functioning and disability in bipolar disorder: An extensive review. Psychother Psychosom. 2009;78(5):285-97.

6. McKay AP, Tarbuck AF, Shapleske J, McKenna PJ. Neuropsychological function in manic-depressive psychosis. Evidence for persistent deficits in patients with chronic, severe illness. Br J Psychiatry. 1995;167(1):51-7.

7. Martínez-Arán A, Vieta E, Reinares M, Colom F, Torrent C, Sánchez-Moreno J, et al. Cognitive function across manic or hypomanic, depressed, and euthymic states in bipolar disorder. Am J Psychiatry. 2004;161(2):262-70.

8. Bortolato B, Miskowiak KW, Köhler CA, Vieta E, Carvalho AF. Cognitive dysfunction in bipolar disorder and schizophrenia: A systematic review of metaanalyses. Neuropsychiatr Dis Treat. 2015;11:3111-25.

9. van Gorp WG, Altshuler L, Theberge DC, Wilkins J, Dixon W. Cognitive impairment in euthymic bipolar patients with and without prior alcohol dependence. A preliminary study. Arch Gen Psychiatry. 1998;55(1):41-6.

10. Demirel A, Demirel ÖF, Kadak MT, Duran A. Ötimik bipolar hastalarda nörobilişsel defisitler. Psikiyatride Güncel Yaklaşımlar. 2012;4(3):381-95.

11. Shefa U, Kim D, Kim MS, Jeong NY, Jung J. Roles of gasotransmitters in synaptic plasticity and neuropsychiatric conditions. Neural Plast. 2018;2018:1824713.

12. Andreazza AC, Kauer-Sant'Anna M, Frey BN, Bond DJ, Kapczinski F, Young LT, et al. Oxidative stress markers in bipolar disorder: A meta-analysis. J Affect Disord. 2008;111(2-3):135-44.

13. Savaş HA, Herken H, Yürekli M, Uz E, Tutkun H, Zoroğlu SS, et al. Possible role of nitric oxide and adrenomedullin in bipolar affective disorder. Neuropsychobiology. 2002;45(2):57-61.

14. Leiper J, Vallance P. Biological significance of endogenous methylarginines that inhibit nitric oxide synthases. Cardiovasc Res. 1999;43(3):542-8.

15. Das I, Khan NS, Puri BK, Hirsch SR. Elevated endogenous nitric oxide synthase inhibitor in schizophrenic plasma may reflect abnormalities in brain nitric oxide production. Neurosci Lett. 1996;215(3):209-11.

16. Gergerlioglu HS, Savas HA, Bulbul F, Selek S, Uz E, Yumru M. Changes in nitric oxide level and superoxide dismutase activity during antimanic treatment. Prog Neuropsychopharmacol Biol Psychiatry. 2007;31(3):697702.

17. Yanik M, Erel O, Kati M. The relationship between potency of oxidative stress and severity of depression. Acta Neuropsychiatr. 2004;16(4):200-3.

18. Selek S, Savas HA, Gergerlioglu HS, Bulbul F, Uz E, Yumru M. The course of nitric oxide and superoxide dismutase during treatment of bipolar depressive episode. J Affect Disord. 2008;107(1-3):89-94.

19. Savas HA, Gergerlioglu HS, Armutcu F, Herken H, Yilmaz HR, Kocoglu E, et al. Elevated serum nitric oxide and superoxide dismutase in euthymic bipolar patients: impact of past episodes. World J Biol Psychiatry. 2006;7(1):51-5.

20. Selley ML. Increased concentrations of homocysteine and asymmetric dimethylarginine and decreased concentrations of nitric oxide in the plasma of patients with Alzheimer's disease. Neurobiol Aging. 2003;24(7):903-7.

21. Selley ML. Increased (E)-4-hydroxy-2-nonenal and asymmetric dimethylarginine concentrations and decreased nitric oxide concentrations in the plasma of patients with major depression. J Affect Disord. 2004;80(2-3):249-56. 
22. Aykut D, Tiryaki A, Özkorumak E, Karahan C. Nitric oxide and asymmetrical dimetihylarginine levels in acute mani. Bull Clin Psychopharmacol. 2012;22(1):10-5.

23. Aydemir Ö, Çubukçuoğlu Z, Erdin S, Taş C, Onur E, Berk M. Oxidative stress markers, cognitive functions, and psychosocial functioning in bipolar disorder: An empirical cross-sectional study. Rev Bras Psiquiatria. 2014;36(4):2937.

24. Karadag F, Oral ET, Yalçin FA, Erten E. Young Mani Derecelendirme Ölçeğinin Türkiye'de Geçerlik ve Güvenilirliği. Türk Psikiyatri Dergisi. 2001;13(2):107-14.

25. Akdemir A, Türkçapar MH, Orsel SD, Demirergi N, Dag I, Ozbay MH. Reliability and validity of the Turkish version of the Hamilton Depression Rating Scale. Compr Psychiatry. 2001;42(2):161-5.

26. Öktem Tanör Ö. Öktem sözel bellek süreçleri testi (ÖKTEMSBST) el kitabı. Ankara: Türk Psikologları Derneği Yayınlar1; 2011.

27. Yalçın K, Karakaş S. Wisconsin kart eşleme testi performansında gelişimin niceliksel ve niteliksel etkileri. Çocuk ve Gençlik Ruh Sağlığı Dergisi. 2007;14(1):24-32.

28. Karakaş S, Irak M, Kurt M, Erzengin ÖU. Wisconsin Kart Eşleme Testi ve Stroop Testi TBAG Formu: Ölçülen özellikler açısından karşılaştırmalı analiz. Psikiyatri Psikoloji Psikofarmakoloji Dergisi. 1999;7(3):179-92.

29. Stroop JR. Studies of interference in serial verbal reaction. J Exp Psychology. 1935;18(6):643-62.

30. Karakaş S, Erdoğan E, Sak L, Soysal AŞ, Ulusoy T, Ulusoy IY, ve ark. Stroop Testi TBAG Formu: Türk kültürüne standardizasyon çalışmaları, güvenirlik ve geçerlik. Klinik Psikiyatri. 1999;2(2):75-88.

31. Reitan RM. Validity of the Trailmaking Test as an indicator of organic brain damage. Percept Mot Skills. 1958;8:271-6.

32. Spreen O, Strauss EA. Compendium of neuropsychological tests: Administration, norms, and commentary. New York: Oxford University Press; 1991.

33. Robinson LJ, Ferrier IN. Evolution of cognitive impairment in bipolar disorder: A systematic review of cross-sectional evidence. Bipolar Disorders. 2006;8(2):103-16.

34. Bora E, Vahip S, Akdeniz F. Bipolar bozuklukta bilişsel belirtilerin doğası ve önemi. Türk Psikiyatri Dergisi. 2008;19(1):81-93.

35. Kulkarni S, Jain S, Janardhan Reddy YC, Kumar KJ, Kandavel T. Impairment of verbal learning and memory and executive function in unaffected siblings of probands with bipolar disorder. Bipolar Disord. 2010;12(6):647-56.

36. Sagar R, Sahu A, Pattanayak RD, Chatterjee B. Assessment of cognitive functions in bipolar I disorder: A 1-year naturalistic follow-up study. Bipolar Disord. 2018;20(3):248-59.

37. Floel A, Poeppel D, Buffalo EA, Braun A, Wu CWH, Seo $\mathrm{HJ}$, et al. Prefrontal cortex asymmetry for memory encoding of words and abstract shapes. Cereb Cortex. 2004;14(4):4049.

38. Martínez-Arán A, Vieta E, Colom F, Torrent C, SánchezMoreno J, Reinares $\mathrm{M}$, et al. Cognitive impairment in euthymic bipolar patients: Implications for clinical and functional outcome. Bipolar Disord. 2004;6(3):224-32.

39. Torres IJ, Boudreau VG, Yatham LN. Neuropsychological functioning in euthymic bipolar disorder: A meta-analysis. Acta Psychiatr Scand Suppl. 2007;(434):17-26.

40. Zubieta JK, Huguelet P, O’Neil RL, Giordani BJ. Cognitive function in euthymic Bipolar I Disorder. Psychiatry Res. 2001;102(1):9-20.

41. Thompson JM, Gallagher P, Hughes JH, Watson S, Gray JM, Ferrier IN, et al. Neurocognitive impairment in euthymic patients with bipolar affective disorder. Br J Psychiatry. 2005; 186:32-40.

42. Mur M, Portella MJ, Martínez-Arán A, Pifarré J, Vieta E. Neuropsychological profile in bipolar disorder: A preliminary study of monotherapy lithium-treated euthymic bipolar patients evaluated at a 2-year interval. Acta Psychiatr Scand. 2008;118(5):373-81.

43. Martinez-Aran A, Vieta E, Torrent C, Sanchez-Moreno J, Goikolea JM, Salamero M, et al. Functional outcome in bipolar disorder: The role of clinical and cognitive factors. Bipolar Disord. 2007;9(1-2):103-13.

44. Martino DJ, Strejilevich SA, Scápola M, Igoa A, Marengo E, Ais ED, et al. Heterogeneity in cognitive functioning among patients with bipolar disorder. J Affect Disord. 2008;109(12):149-56.

45. Arts B, Jabben N, Krabbendam L, van Os J. Meta-analyses of cognitive functioning in euthymic bipolar patients and their first-degree relatives. Psychol Med. 2008;38(6):771-85.

46. Martino DJ, Marengo E, Igoa A, Scápola M, Ais ED, Perinot L, et al. Neurocognitive and symptomatic predictors of functional outcome in bipolar disorders: A prospective 1 year follow-up study. J Affect Disord. 2009;116(1-2):37-42.

47. Bora E, Vahip S, Akdeniz F, Gonul AS, Eryavuz A, Ogut M, et al. The effect of previous psychotic mood episodes on cognitive impairment in euthymic bipolar patients. Bipolar Disord. 2007;9(5):468-77.

48. Cavanagh JT, Van Beck M, Muir W, Blackwood DH. Casecontrol study of neurocognitive function in euthymic patients with bipolar disorder: An association with mania. Br J Psychiatry. 2002;180:320-6.

49. Clark L, Iversen SD, Goodwin GM. Sustained attention deficit in bipolar disorder. Br J Psychiatry. 2002;180:313-9.

50. Nehra R, Chakrabarti S, Pradhan BK, Khehra N. Comparison of cognitive functions between first-and multi-episode bipolar affective disorders. J Affect Disord. 2006;93(13):185-92.

51. Garthwaite J, Boulton CL. Nitric oxide signaling in the central nervous system. Annu Rev Physiol. 1995;57:683706.

52. Kielstein JT, Zoccali C. Asymmetric dimethylarginine: A cardiovascular risk factor and a uremic toxin coming of age? Am J Kidney Dis. 2005;46(2):186-202.

53. Hoekstra R, Fekkes D, Pepplinkhuizen L, Loonen AJM, Tuinier S, Verhoeven WMA. Nitric oxide and neopterin in bipolar affective disorder. Neuropsychobiology. 2006;54(1):75-81.

54. Machado-Vieira R, Andreazza AC, Viale CI, Zanatto V, Cereser V, Vargas R da S, et al. Oxidative stress parameters in unmedicated and treated bipolar subjects during initial manic episode: A possible role for lithium antioxidant effects. Neurosci Lett. 2007;421(1):33-6. 